\title{
MENUMBUHKEMBANGKAN POTENSI ANAK DENGAN PENGENALAN BAHASA INGGRIS SEJAK DINI DALAM KELUARGA
}

\section{GROWING THE DEVELOPMENT OF THE POTENTIAL OF CHILDREN WITH THE ENGLISH RECOGNITION SINCE EARLY IN THE FAMILY}

\author{
Juwita Boneka Sinaga $^{1}$, Junierissa Marpaung ${ }^{2}$

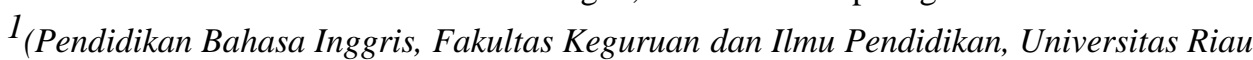 \\ Kepulauan, Indonesia) \\ ${ }^{2}$ (Bimbingan Konseling, Fakultas Keguruan dan Ilmu Pendidikan, Universitas Riau \\ Kepulauan, Indonesia) \\ ${ }^{1}$ juwitaboneka@gmail.com, ${ }^{2}$ junierissa_marpaung@yahoo.com
}

\begin{abstract}
Abstrak
Pengabdian masyarakat ini bertujuan untuk memberikan wawasan tentang menumbuhkembangkan potensi anak dengan pengenalan bahasa Inggris sejak dini dalam keluarga pada masyarakat. Dengan pengenalan bahasa sejak dini dapat merangsang anak menggali potensi bakat yaitu kecerdasan linguistik. Bahasa yang digunakan orangtua untuk berkomunikasi dengan anak sehari-hari berkontribusi pada kemampuan anak dalam berpikir abstrak. Di Indonesia sendiri masih banyak orang yang belum mengusai bahasa Inggris dikarenakan kurangnya pembelajaran yang mereka dapatkan atau baru mendapatkan pembelajaran bahasa asing ketika usia mereka sudah dewasa, sehingga daya tangkap otak sudah kurang optimal. Sasaran pengabdian adalah masyarakat di RW 01 Kelurahan Sungai Langkai Kota Batam. Persiapan dilakukan dengan survei pendahuluan untuk melihat kondisi di lapangan mengenai masalah yang dihadapi masyarakat. Pelaksanaan dilakukan dengan memberikan layanan informasi menggunakan metode ceramah berupa penyuluhan yaitu dengan teknik presentase, dilanjutkan dengan diskusi dan tanyajawab. Hasil kegiatan penyuluhan menunjukkan bahwa: (1). Program pengabdian pada masyarakat dengan kegiatan penyuluhan tentang menumbuhkembangkan potensi anak dengan pengenalan Bahasa Inggris sejak dini dalam keluarga di RW 01 Kelurahan Sungai Langkai Kota Batamdapat dilaksanakan dan direspon dengan baik. (2). Pelaksanaan program pengabdian pada masyarakat ini sangat bermanfaat bagi masyarakat sehingga dapat diterapkan para orang tua dengan keterbatasan guna menumbuhkembangkan potensi anak dalam berbahasa Inggris sejak dini.
\end{abstract}

Kata Kunci: Potensi Diri, Pengenalan Bahasa Inggris, Anak Usia Dini

\begin{abstract}
This community service aims to provide insight into knowledge about developing the potential of children with the introduction of English from an early age in the family in the community. With early language recognition, it can stimulate children to explore the potential of children's talents, namely linguistic intelligence. The language used by parents to communicate with children everyday contributes to the child's ability to think abstractly. In Indonesia, there are still many people who have not mastered English because of the lack of learning they get or have just received foreign language learning when they are older, so that the brain's catching power is less than optimal. The target of service is the community in RW 01 Sungai Langkai
\end{abstract}


Village, Batam City. Preparation is carried out by conducting a preliminary survey to see the conditions in the field regarding the problems faced by the community. The implementation is carried out by providing information services using the lecture method in the form of counseling, namely the percentage technique, followed by discussion and question and answer. The results of the extension activities showed that: (1). Community service program with counseling activities about developing the potential of children with the introduction of English from an early age in the family in RW 01 Sungai Langkai Village, Batam City can be implemented and responded well. (2). The implementation of this community service program is very beneficial for the community so that parents can apply it with limitations in order to develop the potential of children in English from an early age.

Keywords: Self Potential, Introduction to English, Early Childhood

\section{PENDAHULUAN}

Dalam menghadapi MEA (Masyarakat Ekonommi Asean), bahasa Inggris perlu diajarkan sejak dini agar sejak kecil anak sudah terbiasa mendengar dan mengucapkan bahasa Inggris, sehingga nanti ketika besar mereka sudah mahir menggunakan bahasa Inggris sebagai alat komunikasi dan mampu meningkatkan perekonomian mereka (Putri, 2017).

Usia dini merupakan masa keemasan (golden age), oleh karena itu pendidikan pada masa ini merupakan pendidikan yang sangat fundamental dan sangat menentukan perkembangan anak selanjutnya. Apabila anak mendapatkan stimulus yang baik, maka seluruh aspek perkembangan anak akan berkembang secara optimal. Oleh karena itu, pendidikan anak usia dini harus dapat merangsang seluruh aspek perkembangan anak baik perkembangan perilaku, bahasa, kognitif, seni maupun fisik motoric.

Bahasa merupakan aspek penting dalam perkembangan pada masa bayi dan anak-anak, Menguasai bahasa memungkinkan anak untuk dapat berinteraksi dengan lingkungannya secara efektif. Anak usia 4-5 tahun berada pada tahap pra operasional, yang mana pada tahap ini anak mulai mengembangkan kemampuan berbahasanya. Menurut (Saurina. 2016) Pemerolehan bahasa pada anak usia dini meliputi 2 tahapan yaitu pemerolehan bahasa pertama dan pemerolehan bahasa kedua (bahasa asing). Bahasa pertama sering disebut juga bahasa ibu, karena anak pertama kali berinteraksi dan belajar dengan ibu (bahasa yang dipakai dalam keluarga). Sedangkan bahasa 
kedua adalah bahasa anak yang diperoleh setelah bahasa pertama. Bahasa kedua anak di Indonesia pada umumnya bahasa Indonesia dan asing (bahasa Inggris).

Bahasa adalah alat berpikir, mengekspresikan diri dan berkomunikasi. Keterampilan bahasa penting dalam rangka pembentukan konsep, informasi, dan pemecahan masalah. Melalui bahasa kita dapat memahami pikiran dan perasaan, serta berkomunikasi. Bloom \& Lahey (Jabet, 2016) mendefinisikan, "Bahasa merupakan suatu kode dimana gagasan/ide tentang dunia/lingkungan diwakili oleh seperangkat lambang yang telah disepakati bersama untuk melangsungkan komunikasi”.

Perkembangan bahasa anak sebenarnya sudah dimulai sejak anak lahir (Arumsari, 2017) dengan menggunakan bahasa atau prawicara yang paling sederhana yaitu "menangis", kemudian perkembangan dalam bentuk"celoteh/ocehan", kata/kalimat sederhana disertai gerakan tubuh/syarat sebagai pelengkap bicara. Dalam psikologi pendidikan dikenal adanya teori pembelajaran yang dapat digunakan sebagai landasan pengajaran Bahasa berfungsi sebagai sarana berkomunikasi antar manusia. Pada anak usia dini bahasa berfungsi sebagai alat untuk mengembangkan kemampuan intelektualnya yang sedang pesat dan fundamental. Gardner (Jabet.2016) berpendapat bahwa fungsi bahasa bagi anak usia dini ialah sebagai alat mengembangkan kemampuan intelektual dan kemampuan dasar anak". (Jabet.2016) menjelaskan bahwa pembelajaran adalah pemerolehan suatu mata pelajaran, pengalaman, atau pengajaran. Belajar bahasa adalah proses penguasaan bahasa, baik bahasa pertama maupun bahasa kedua, serta bahasa asing yang tidak digunakan dalam komunikasi sehari-hari. Krashen (Jabet, 2016) menyatakan bahwa penguasaan bahasa meliputi penguasaan secara alamiah (acquisition) maupun secara formal (learning). Kedua proses tersebut mengisyaratkan kepada kita bahwa proses alamiah maupun proses secara formal sedikit banyak akan mempertimbangkan aspek psikologi bagi pembelajarnya. 


\section{METODOLOGI}

\section{Material}

Sebenarnya proses pembelajaran itu dapat dilakukan di rumah dengan melibatkan orang-orang di sekitar anak tersebut seperti orang tua atau caretaker. (Suciati.2017) menyatakan bahwa orang tua dapat mengambil peran aktif untuk memperkenalkan Bahasa Inggris kepada putra putrinya sejak dini. Tentu saja materi pembelajaran itu perlu dikemas sedemikian rupa sehingga anak tertarik untuk mempelajarinya. Tanpa disadarinya ketika sedang bermain, anak tersebut telah masuk dalam proses pembelajaran. Berikut ini adalah kegiatan pembelajaran Bahasa Inggris yang dapat dilakukan di rumah.

Pertama kali yang harus diperhatikan adalah suasana ruangan dimana anak melakukan aktivitas pembelajaran. Menurut (Gunawan. 2014) Kita harus dapat menciptakan suasana yang relax pada saat proses pembelajaran berlangsung. Selain itu materi harus dikemas semenarik mungkin karena anakanak cenderung mudah bosan terhadap aktivitas yang monoton.

1. Sebagai perkenalan awal terhadap Bahasa Inggris, kita dapat menggunakan lagu-lagu berbahasa Inggris. Ini adalah salah satu cara untuk memasukkan unsur Bahasa itu ke dalam pikiran anak sehingga anak akan terbiasa mendengarkan kata-kata yang dinyanyikan dalam lagu tersebut. Selanjutnya mereka dengan mudah ikut menyanyikan lagu-lagu tersebut seperti yg dikemukakan oleh (Sinaga. 2017), kita dapat memulainya dengan lagu-lagu sederhana yang mudah diterima anak, seperti lagu $A B C$. Seiring dengan perkembangan kemampuan anak, kita dapat memberikan lagu-lagu yang lebih complex, seperti Old Mac Donald.

2. Kita juga dapat menggunakan film animasi sebagai media untuk menarik minat anak mempelajari Bahasa Inggris. Warna yang cerah dan pronounciation (pelafalan kata) yang sangat jelas dalam film tersebut dapat membuat anak mudah mengerti dan dapat mengasah kemampuan mereka untuk menguasai vocabulary dan grammar. Carilah film animasi yang memang dibuat untuk belajar Bahasa Inggris. Kita dapat memulainya dengan 
film yang sederhana, seperti Dora the Explorer, yang setelah itu dikembangkan dengan film yang lebih complex, seperti Disney movies.

3. Internet juga dapat digunakan sebagai sumber pembelajaran. Banyak program online yang dapat digunakan sebagai materi pembelajaran seperti game, song, dan aktivitas yang lain.

4. Menguasai grammar memang bukan hal yang mudah bagi anak yang belajar Bahasa Inggris sebagai Bahasa kedua. Belajar grammar juga hal yang membosankan bagi mereka. Maka kita harus dapat memciptakan proses pembelajaran yang menarik buat anak. Kita dapat menggunakan lagu untuk mengajar grammar kepada anak. Kita dapat memulainya dengan mencari lagu yang mengandung unsur grammar yang ingin kita ajarkan kepada anak.

\section{Metode}

Dalam program sosialisasi ini, digunakan beberapa metode, menurut (Arumsari. 2018) antara lain :

1. Metode Ceramah, yaitu digunakan untuk memaparkan materi yang telah disusun leh Tim Pelaksana.

2. Metode Tanya Jawab, yaitu digunakan untuk merespon sejauh mana tingkat pemahaman peserta sosialisasi terhadap yang telah disampaikan oleh Tim Pelaksana Pengabdian Kepada Masyarakat Universitas Riau Kepulauan.

3. Metode Diskusi, yaitu pemateri dan peserta melakukan dialog yang membahas masalah seputar Menumbuh kembangkan Potensi Anak Dengan Pengenalan Bahasa Inggris Sejak Dini Dalam Keluarga

4. Metode Simulasi dan Praktik, yaitu digunakan untuk memperlihatkan penggunaan Pengenalan Bahasa Inggris Sejak Dini Dalam Keluarga

\section{PEMBAHASAN}

Banyak yang tidak mengetahui bahwa sebenarnya mengajarkan bahasa asing pada anak-anak sejak usia dini sangat diperlukan. Bahkan, pendidikan bahasa asing akan sangat ideal jika dimulai sejak usia dini, terutama sebelum mereka menginjak umur 12 tahun. Salah satu bahasa asing yang dapat diajarkan 
adalah bahasa Inggris..

Departemen Pendidikan Nasional menetapkan bahwa kemampuan yang harus dimiliki oleh siswa Indonesia adalah memahami dan mengungkapkan informasi, pikiran, perasaan, serta mengembangkan ilmu pengetahuan, teknologi, dan budaya dengan menggunakan bahasa Inggris. Bahasa Inggris berfungsi sebagai alat untuk berkomunikasi dalam rangka mengakses informasi dan sebagai alat untuk membina hubungan interpersonal maupun bertukar informasi (Arumsari, 2017).

Penguasaan bahasa Inggris yang masih rendah pada anak usia dini tersebut disebabkan karena latar belakang keluarga yang kurang mendukung pembelajaran bahasa Inggris (Suciati. 2017), pendekatan pembelajaran yang kurang menarik, pemilihan bahan ajar bahasa Inggris yang kurang tepat, komunikasi yang kurang hangat, serta penggunaan media yang kurang variatif dalam pembelajaran bahasa Inggris pada anak usia dini.

Dalam upaya ikut membantu mengajarkan bahasa Inggris pada anak usia dini, salah satunya adalah dengan pembuatan media pembelajaran bahasa Inggris yang memanfaatkan alat teknologi (Nurzaman. 2017), seperti komputer. Pembelajaran dengan komputer akan lebih membantu anak-anak untuk memahami materi yang disajikan dalam bentuk bahasa Inggris seperti pengenalan hewan, warna, angka, menyebutkan anggota keluarga dan lain sebagainya. Media pembelajaran ini juga akan lebih mempermudah anak-anak dalam belajar, karena menggunakan gambar serta audio untuk melatih bagaimana cara membaca dan melafalkan huruf-huruf dalam bahasa Inggris dengan benar. Selain itu, dengan adanya media pembelajaran ini diharapkan mampu memberikan kesan yang baik sehingga anak-anak ingin mempelajari bahasa Inggris dalam jangka waktu yang lama dan berkelanjutan sampai mereka dewasa.

Peran aktif orang tua sangat diperlukan dalam hal ini, dengan kata lain orang tua pun dituntut untuk mengetahui sedikit tentang bahsa Inggris agar mereka bisa membeli buku tentang dasar bahasa Inggris dan mengajarkannya pada anak-anak mereka di rumah. 
Di bawah ini adalah beberapa alasan mengapa anak sejak dini harus dituntut untuk menguasai bahasa Inggris, antara lain (Sunarni, 2009):

1. Faktor geografis menjadi alasan pertama mengapa orang Indonesia perlu mempelajari bahasa Inggris. Indonesia dikelilingi oleh negara-negagara yang kebanyakan penduduknya menggunakan bahasa Inggris sebagai bahasa pertama atau kedua. Negara-negara tersebut antara lain Singapura, Malaysia, Filiphina, Australia, dan lain sebagainya. Dengan belajar bahasa Inggris akan memudahkan seseorang dalam berkomunikasi dengan orang lain apabila suatu saat pergi ke luar negeri.

2. Bahasa Inggris perlu dipelajari karena penggunaannya secara luas sebagai bahasakomunikasi internasional. Agar dapat berkomunikasi dengan orangorang yang berbeda latar belakang budaya dan kenegaraannya, bahsa Inggris menjadi pilihan utama yang sering dipakai dalam melakukan komunikasi. Contoh yang mudah dilihat ada pada dunia pariwisata. Selain itu, bahasa Inggris juga menjadi bahasa pengantar resmi dalam dunia transportasi baik di udara maupun di laut.

3. Informasi yang terdapat di dunia juga kebanyakan menggunakan bahasa Inggris sebagai bahasa publikasinya. Bisa kita ambil contoh dari internet, sebagian besar situs-situs penyedia informasi di internet berbahasa Inggris. Tidak hanya di internet, buku-buku juga tidak sedikit yang memakai bahasa Inggris. Dengan lancar berbahasa Inggris akan sangat membantu anak dalam menjelajah dan mengakses sumber pengetahuan baik dari media tulis maupun media elektronik.

\section{Pendekatan Teori Pembelajaran Bahasa Inggris Untuk Anak Usia Dini}

Sebagai seorang pendidik anak usia dini sebelum mereka memulai pembelajaran, mereka harus mengetahui karakteristik anak-anak yang dididik terlebih dahulu (Mainizar. 2013), karena itu membantu mereka dalam memudahkan perkembangan anak-anak dalam pembelajaran.

Adapun secara umum karakteristik anak-anak usia dini yang dimaksud, antara lain:

\section{a. Aspek Kognitif}


1. Mereka telah memiliki kemampuan untuk mengintepretasikan arti/makna.

2.Mereka memiliki daya perhatian dan konsentrasi yang terbatas.

3.Mereka telah memiliki daya untuk berimaginasi. 4.Mereka memahami situasi.

\section{b. Aspek Afektif}

1. Mereka senang menemukan dan menciptakan sesuatu yang baru.

2. Mereka senang berbicara.

3. Mereka senang bermain dan bekerja sendiri.

4. Mereka tertarik pada aktivitas yang sesuai dengan mereka.

c. Aspek Psikomotorik

1. Mereka memiliki keterampilan dalam bahasa secara terbatas namun kreatif.

2. Mereka dapat belajar dengan melakukan sesuatu.

3. Mereka belajar bahasa Inggris dengan mempraktikannya.

4. Mereka dapat bekerja sama dengan orang dewasa.

5. Mereka akan belajar dengan sangat baik apabila mereka terlibat dalam aktivitas yang sesuai dengan diri mereka.

Dengan memperhatikan karakteristik anak-anak tersebut, tujuan pembelajaran bahasa Inggris untuk anak usia dini secara umum dapat ditentukan sebagai berikut:

1. Membuat anak merasa berkompeten dan percaya diri dalam bahasa Inggris.

2. Menyediakan lingkungan pembelajaran yang aman, bersifat menghibur dan rekreatif serta mendidik.

3. Menciptakan pembelajar bahasa Inggris untuk jangka panjang.

\section{Tahapan-tahapan Dalam Belajar Bahasa Inggris}

Pengajaran bahasa Inggris dilakukan secara bertahap. Sama halnya dengan belajar bahasa Indonesia anak tidak langsung berbicara, membaca dan menulis secara bersamaan. Sebelum bisa berbicara dalam bahasa Indonesia mereka harus mendengarkan terlebih dahulu bahasa Indonesia. Jika mereka tidak pernah mendengarkannya mereka akan mengalami kesulitan dalam berbicara. Itu 
sebabnya biasanya anak yang tuli juga otomatis bisu karena dia tidak bisa mendengar sehingga tidak bisa menirukannya. Jadi, pada intinya belajar bahasa apapun caranya sama. Berikut ini adalah tahapan-tahapan dalam belajar bahasa Inggris bagi anak (Arumsari. 2017):

\section{Listening (Mendengar)}

Selain mendengar kita berbicara, anak juga bisa mendengar dengan cara dibacakan buku cerita dalam bahasa Inggris,mendengar nyanyian sederhana ataupun menonton DVD atau video berbahasa Inggris. Tapi untuk pengetahuan awal, sebagai pendidik kita harus memilih kata-kata yang sedikit dan sederhana.

\section{Speaking (Berbicara)}

Setelah anak sering mendengar dalam bahasa Inggris, anak bisa didorong untuk berbicara dalam kalimat-kalimat sederhana. Misalnya, dengan menerapkan waktu 30 menit sehari sebagai waktu keluarga untuk berbicara dalam bahasa Inggris. Layaknya anak usia balitayang baru memulai berbicara, anak juga memulai berbicara dalam bahasa Inggris meskipun dengan satu kata seperti book (buku) ketika melihat kakaknya membawa buku. Lalu kembangkan menjadi kalimat-kalimat pendek seperti, she brings book.

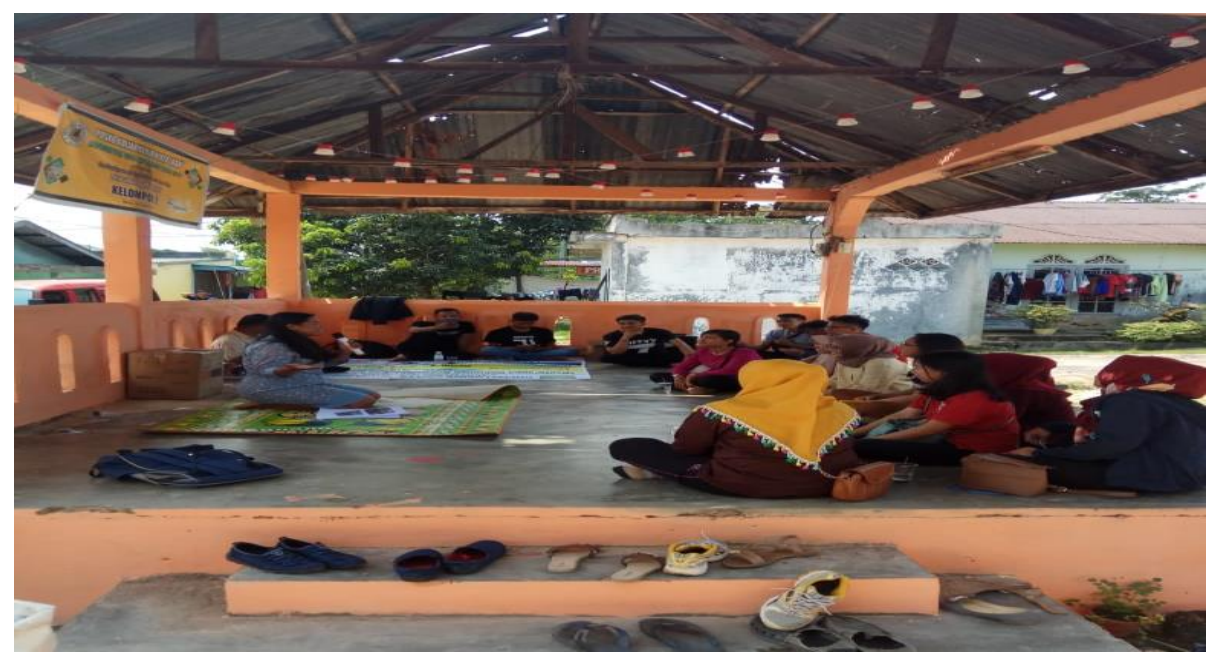

Figure 1. Foto Proses pembelajaran speaking sederhana. 


\section{Reading (Membaca)}

Ada dua metode umum dalam mengajarkan anak belajar membaca dalam bahasa Inggris (Saptiani. 2016) yaitu whole language approachdan phonic.

a. Whole language approach adalah suatu metode belajar membaca dengan menjadikan bahasa sebagai salah satu kesatuan tidak terpisah-terpisah.belajar membaca juga harus sesuai dengan konteksnya. Metode ini lebih menekankan pada arti suatu kata. Contohnya, ketika melihat kata "cat" (kucing) anak langsung diberitahu bahwa itu bacanya "ket" dan itu artinya kucing. Biasanya anak belajar membaca dengan sistem mengingat (memorize) kata yang sudah pernah disebutkan. Kelebihan metode ini adalah anak lebih cepat bisa membaca tapi akan kesulitan ketika harus menuliskan kata yang dimaksud terutama kata-kata yang cukup panjang.

b. Phonic adalah suatu metode belajar membaca melalui huruf dengan cara mengejanya satu persatu, misalkan "cat" (kucing) berarti dieja "keh-e-teh" dan dibaca "ket". Setiap kata diurai menjadi huruf-huruf. Karena belajar melalui mengeja maka anak memerlukan waktu yang lebih lama untuk bisa membaca. Tapi kelebihannya anak lebih mudah ketika harus menuliskan kata yang dia dengar. Untuk memudahkan anak belajar dan membaca, kita sebagai pendidik sebaiknya memilih buku-buku yang sesuai dengan tingkatannya. Misalnya, anak yang baru mulai membaca, sebagai pendidik kita memilih buku-buku yang hanya terdiri dari satu kata misalkan halaman pertama ada gambar buah apel dan di bawahnya ada tulisan This is Apple.Setelah itu bisa dicoba dengan kata yang lain, misalkan I like banana. Anak bisa membuat sendiri buku-buku seperti itu atau mendapatkannya melalui reading $\mathrm{A}$ to $\mathrm{Z}$.

\section{Writing (Menulis)}

Ini adalah tahapan yang paling sulit dalam belajar bahasa Inggris, karena ada banyak aturan yang harus dipatuhi. Biasanya orang Indonesia pasti akan kesulitan untuk berbicara dalam bahasa Inggris. Sebenarnya bukan karena tidak bisa melainkan karena takut salah. Padahal meskipun kita salah mengucapkan susunan beberapa kalimat atau salah kata bahasanya lawan 
bicara kita pasti mengerti. Tapi lain halnya dengan menulis, ketika kita melakukan banyak sekali kesalahan tata bahasa dan cara pengejaan bisa jadi orang yang membaca tulisan kita tidak mengerti apa yang kita tulis. Karena ini relatif sulit, maka menulis menjadi tahapan terakhir. Sebagai pendidik kita tidak boleh terburu-buru mengajarkan grammar atau menulis apabila anak belum menguasai tiga tahap sebelumnya.

Hal-hal yang perlu diperhatikan dalam melakukan kegiatan pembelajaran bahasa Inggris untuk anak usia dini (Gunawan. 2014) agar pembelajaran tersebut dapat mencapai tujuan seperti yang diharapkan:

1. Melengkapi aktivitas pembelajaran dengan media visual dan gerakan-gerakan serta kombinasi antara 'bahasa lisan' dengan 'bahasa tubuh' atau 'demonstrasi' .

2. Melibatkan anak-anak di dalam pembuatan media visual.

3. Berpindah dari aktivitas yang satu ke aktivitas yang lain dengan cepat.

4. Membangun rutinitas di dalam kelas dengan menggunakan bahsa Inggris.

5. Gunakan bahasa ibu apabila diperlukan.

6. Mengajar berdasarkan tema dan menstimulasi imajinasi dan kreativitas anakanak.

7. Mengunakan cerita dan konteks yang sudah dikenal oleh anak-anak.

8. Mengundang masyarakat sekitar (orang tua, mahasiswa, dsb.) yang bisa berbahasa Inggris untuk bercerita di dalam kelas.

9. Berkolaborasi dengan guru lain di sekolah kita.

10.Berkomunikasi dengan guru atau pengajar untuk anak usia dini lainnya di luar sekolah tempat kita mengajar

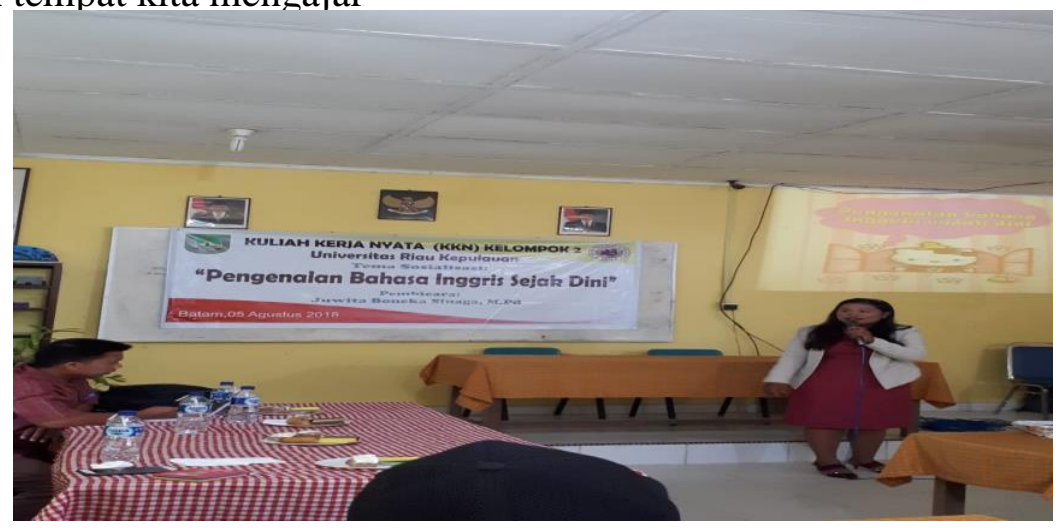

Figure 2. Foto Sosialisai Pengenalan bahasa inggris bagi orangtua 
untuk diajarkan pada anak usia dini

\section{KESIMPULAN DAN SARAN}

Pengajaran bahasa Inggris dilakukan secara bertahap. Sama halnya dengan belajar bahasa Indonesia anak tidak langsung berbicara, membaca dan menulis secara bersamaan. Sebelum bisa berbicara dalam bahasa Indonesia mereka harus mendengarkan terlebih dahulu bahasa Indonesia. Jika mereka tidak pernah mendengarkannya mereka akan mengalami kesulitan dalam berbicara. Itu sebabnya biasanya anak yang tuli juga otomatis bisu karena dia tidak bisa mendengar sehingga tidak bisa menirukannya. Jadi, pada intinya belajar bahasa apapun caranya sama.

\section{DAFTAR PUSTAKA}

Arumsari, Andini Dwi dkk. 2017. Pembelajaran Bahasa Inggris Pada Anak Usia Dini Di Kecamatan Sukolilo Surabaya. Jurnal PG-PAUD Trunojoyo Vol. 4(2): 82-170.

Gunawan. Veronica, dkk. 2014. Peningkatan Kemampuan Pengucapan Bahasa Inggris Melalui Metode Bernyanyi Pada Anak Usia 5-6 Tahun. Jurnal Pendidikan dan Pembelajaran UNTAN Vol. 3(8).

Jabet, Aquilina Prily dkk. 2016. Pembelajaran Pengenalan Bahasa Inggris Pada Anak Kelompok A Di Taman Kanak-Kanak Kristen Immanuel II. Jurnal Pendidikan dan Pembelajaran Vol.5(10):1-13.

Mainizar. 2013. Peranan Orang Tua Dalam Pembinaan Dan Pengembangan Bahasa Pada Anak Usia 2-6 Tahun. Jurnal Marwah Fakultas Tarbiyah dan Keguruan UIN Suska Riau Vol. XII(1).

Nurzaman. Istikhoroh, dkk. 2017. Penggunaan Permainan Pesan Gambar Berantai Untuk Meningkatkan Kosa Kata Bahasa Inggris Anak Usia Dini. Jurnal PAUD Agopedia Tasikmalaya Vol.1(1): 40-52.

Putri. Aprilia Riyana. 2017. Pengembangan Materi Bahasa Inggris Untuk Anak Usia Dini Di PAUD Pelangi Guyangan. Jurnal Edulingua Jepara Vol.4(1). 
Saptiani. 2016. Pengembangan Media Pembelajaran Kamus Tematik Tiga Bahasa (Indonesia, Arab, Inggris) Untuk Menstimulasi Kognitif Anak Usia Dini. Jurnal Ar-Raniry Yogyakarta Vol. 1(2): 100-118.

Saurina. Nia 2016. Pengembangan Media Pembelajaran Untuk Anak Usia Dini Menggunakan Augmented Reality. Jurnal IPTEK Surabaya Vol. 20(1).

Sinaga. JB. 2017. Bimbingan Belajar Bahasa Inggris untuk anak usia dini di Kelurahan Buliang RW.18. Jurnal Minda Baharu. Vol. 1(1):33-41

Suarni.Eti 2009. Peranan Orang Tua Dalam Membimbing Bakat Anak Usia 612 Tahun. Skripsi. Tidak Diterbitkan. Fakultas Tarbiyah Dan Keguruan. Universitas Islam Negeri Syarif Hidayatullah: Jakarta.

Suciati. 2017. Peran Orang Tua Dalam Pengembangan Anak Usia Dini. Jurnal STAIN Kudus Thufula 5(2). 